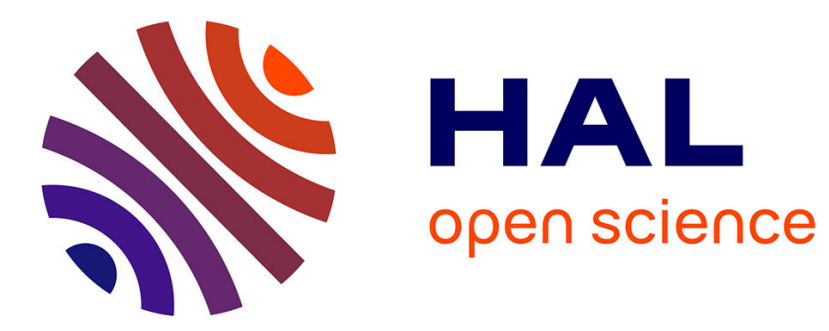

\title{
Epigenetic changes in the early stage of silica-induced cell transformation
}

Carole Seidel, Anaïs Kirsch, Caroline Fontana, Athanase Visvikis, Aurélie Rémy, Laurent Gaté, Christian Darne, Yves Guichard

\section{- To cite this version:}

Carole Seidel, Anaïs Kirsch, Caroline Fontana, Athanase Visvikis, Aurélie Rémy, et al.. Epigenetic changes in the early stage of silica-induced cell transformation. Nanotoxicology, 2017, 11 (7), pp.923 - 935. 10.1080/17435390.2017.1382599 . hal-01715151

\author{
HAL Id: hal-01715151 \\ https://hal.science/hal-01715151
}

Submitted on 22 Feb 2018

HAL is a multi-disciplinary open access archive for the deposit and dissemination of scientific research documents, whether they are published or not. The documents may come from teaching and research institutions in France or abroad, or from public or private research centers.
L'archive ouverte pluridisciplinaire HAL, est destinée au dépôt et à la diffusion de documents scientifiques de niveau recherche, publiés ou non, émanant des établissements d'enseignement et de recherche français ou étrangers, des laboratoires publics ou privés. 


\section{Epigenetic changes in the early stage of silica-induced cell transformation}

Carole Seidel $^{1}$, Anaïs Kirsch ${ }^{1}$, Caroline Fontana ${ }^{1}$, Athanase Visvikis ${ }^{2}$, Aurélie Remy $^{1}$, Laurent Gaté ${ }^{1}$, Christian Darne ${ }^{1}$, Yves Guichard ${ }^{1}$

${ }^{1}$ Département Toxicologie et Biométrologie, Institut National de Recherche et Sécurité (INRS), 1 Rue du Morvan, CS 60027, 54519 Vandoeuvre-lès-Nancy Cedex, France

${ }^{2}$ Ingénierie Moléculaire et Physiopathologie Articulaire (IMoPA), UMR 7365 CNRSUniversité de Lorraine, Biopôle, Campus Biologie Santé, 9 Avenue de la forêt de Haye, CS 50184, 54505 Vandoeuvre-lès-Nancy, France

\section{Corresponding author:}

Département Toxicologie et Biométrologie, Institut National de Recherche et Sécurité (INRS), Rue du Morvan, CS 60027, 54519 Vandoeuvre Les Nancy Cedex, France E-mail address: carole.seidel@inrs.fr

Phone number: +33(0)383 508503 


\title{
Epigenetic changes in the early stage of silica-induced cell transformation
}

\begin{abstract}
The increasing use of nanomaterials in numerous domains has led to growing concern about their potential toxicological properties, and the potential risk to human health posed by silica nanoparticles remains under debate. Recent studies proposed that these particles could alter gene expression through the modulation of epigenetic marks, and the possible relationship between particle exposure and these mechanisms could represent a critical factor in carcinogenicity. In this study, using the Bhas 42 cell model, we compare the effects of exposure to two transforming particles, a pyrogenic amorphous silica nanoparticle NM-203 to those of the crystalline silica particle Min-U-Sil® 5. Short-term treatment by Min-USil® 5 decreased global DNA methylation and increased the expression of the two de novo DNMTs, DNMT3a and DNMT3b. NM-203 treatment affected neither the expression of these enzymes nor DNA methylation. Moreover, modified global histone H4 acetylation status and HDAC protein levels were observed only in the Min-U-Sil® 5-treated cells. Finally, both types of particle treatment induced strong c-Myc expression in the early stage of cell transformation and this correlated with enrichment in RNA polymerase II as well as histone active marks on its promoter. Lastly, almost all parameters that were modulated in the early stage were restored in transformed cells suggesting their involvement mainly in the first steps of cell transformation.
\end{abstract}

Key words: Promotion assay, silica particles, $c$-myc expression, epigenetic modifications 


\section{Introduction}

Over the last decades, the use of nanomaterials has emerged in industrial and medical domains for their particular physicochemical properties. However, the potential risks for human health posed by nanoparticles are not fully known and remain under debate, in part due to difficulties in evaluating the frequency, duration and concentrations of human exposure. An increasing number of studies have been devoted to the evaluation of nanomaterial toxicity. However, the general toxicological profiles of nanomaterials are complex to define due to differences in their physicochemical properties (Bakand and Hayes, 2016). The International Agency for Research on Cancer (IARC) has classified several particles, including crystalline silica particles, as carcinogens for humans, whereas amorphous silica particles, such as silica nanoparticles, have been classified in Group 3 (not classifiable as to its carcinogenicity to humans) (monographs, 1997). Numerous epidemiological, in vivo and in vitro studies using crystalline silica have shown accumulation and activation of macrophages, an increase in neutrophils, the release of chemokines, and inflammation (Johnston et al., 2000, Mischler et al., 2016). In addition, silica particles can induce oxidative stress leading to DNA damage and are responsible for gene silencing through DNA methylation of genes involved in cell cycle regulation (Belinsky et al., 2002, Deshpande et al., 2002, Knaapen et al., 2002). While treatment by the crystalline silica microparticle Min-U-Sil@ 5 induced in vitro neoplastic transformation, treatment by amorphous silica nanoparticles did not induce BALB/3T3 or SHE cell transformation (Darne et al., 2016, Saffiotti and Ahmed, 1995, Uboldi et al., 2012). However, recent studies described that synthetic amorphous silica nanoparticles induce in in vitro models oxidative stress and genotoxic effects or in in vivo models cellular cell death and fibrosis (Guichard et al., 2016, Murugadoss et al., 2017). Moreover, nanosilica particle treatments provoked 
epigenetic changes included changes in global DNA methylation, in methylation of specific sequences such as promoters of tumor suppressor genes or transposable elements, and in DNA methyltransferase (DNMT) expression (Bhattacharjee and Paul, 2016, Di Cristo et al., 2016, Gong et al., 2012, Gong et al., 2010, Lu et al., 2016, Stoccoro et al., 2013). We have recently shown that Min-U-Sil ${ }^{\circledR} 5$ and NM-203 induce transformation in Bhas 42 cell model under promotion conditions (Fontana et al., In press).

Carcinogenetic processes include aberrant epigenetic modifications that are involved in the establishment and maintenance of altered cellular phenotypes (Wilting and Dannenberg, 2012). Epigenetic modifications, including DNA methylation and histone posttranslational modifications, regulate the chromatin dynamics leading to the reprogramming of gene expression. An open chromatin state is induced by, among others, an increase in histone acetylation, methylation of specific histone residues and DNA hypomethylation, allowing the recruitment of transcription factors, RNA polymerase, and other proteins that promote gene transcription (Geiman and Robertson, 2002). On the other hand, compaction of chromatin, thought to lead to transcription inhibition, is associated with histone hypoacetylation and an increase in DNA methylation. Aberrant DNA methylation and histone modifications appear to be early events in tumorigenesis and result from alterations in the activity of chromatinmodifying enzymes. It is generally accepted that global DNA hypomethylation in cancer cells is related to a lack of DNA methylation maintenance by DNMT1, leading to genome instability and increased expression of genes involved in invasion and metastasis (Gama-Sosa et al., 1983). In contrast, the repression of tumor suppressor genes seems to be a consequence of an overexpression of the de novo DNMTs, DNMT3a and DNM3b, which are responsible for hypermethylation of their promoters (Weber et al., 2005). Cancer cells also show altered patterns of histone post-translational modifications, and down or up-regulation of the enzymes involved can also appear early in tumorigenesis. For example, Wilting and 
Dannenberg (2012) observed that disturbance of the expression and/or activity of histone deacetylase (HDAC) isoenzymes led to a disruption in the balance between histone acetyltransferase (HAT) and HDAC activity, which was shown to be associated with cellular transformation. HDAC overexpression could lead to histone hypoacetylation associated with inhibition of tumor suppressor gene expression (Bradbury et al., 2005).

Among the oncogenes responsible for cell transformation, $c$-myc gene overexpression has been widely observed in various cancer types (20\% of human cancers) and has been associated with aggressiveness and poor prognosis (Pelengaris et al., 2002). The alteration of $c$-myc expression in tumor cells could be a consequence of multiple mechanisms, such as chromosome translocation, mutations, gene amplification or modification of histone acetylation on its promoter (Koenig et al., 2010, Pelengaris et al., 2002). The $c$-myc gene codes a transcription factor that, when it heterodimerizes with its partner protein Max, binds to specific DNA sequences (e.g. the E-box sequence) and promotes gene expression (Pelengaris et al., 2002). The transcription factor c-Myc might also repress transcription through interaction with other factors such as Sp1 (Gartel et al., 2001). Consequently, the expression of 10 to $15 \%$ of all the genes transcribed by RNA polymerase II is controlled by c-Myc, including genes that are involved in cell growth and proliferation, regulation of metabolic pathways, cell differentiation, apoptosis, protein synthesis, cell adhesion, angiogenesis, and other processes (Lin et al., 2012, O'Connell et al., 2003).

The aim of this study was to investigate epigenetic modifications induced by silica particles during the early stage of the cell transformation process. An amorphous silica nanoparticle (NM-203), one of the representative silica nanomaterials produced in industry, was tested alongside Min-U-Sil® 5, a crystalline silica particle often used as a benchmark particle in toxicological studies such as cell transformation assay. We used the in vitro Bhas 42 cell transformation assay developed by Sasaki et al. (1988), which was recently the 
subject of an Organization for Economic Cooperation and Development (OECD) guidance document (OECD, 2016, Sasaki et al., 1988). The effects of silica particles on global DNA methylation and histone acetylation, as well as on expression of enzymes involved in epigenetic modifications, were characterized. The impact of these epigenetic marks on the expression of c-Myc was also investigated, focusing on the occupancy of the promoter by RNA polymerase II as well as on enrichment of histone active marks. 


\section{Materials and methods}

\section{Compounds and particles}

Min-U-Sil@ 5 was obtained from US Silica Co. (Berkeley Springs, WV, USA), whereas NM203 was obtained from the Joint Research Centre nanomaterials repository (Ispra, Italy). Particles were dispersed in sterile water and sonicated for 5 min at $10 \%$ amplitude using a Branson Sonifier S-450D equipped with a cup-horn device (Branson Ultrasonics Crop, Danbury, CT). The physical and chemical characteristics of the silica samples are presented in Table S1 (Elias et al., 2006, Rasmussen et al., 2013). 3-methylcholanthrene (MCA, SigmaAldrich, Saint Quentin Fallavier, France, ref\# 213942), 12-O-tetradecanoylphorbol-13acetate (TPA, Sigma-Aldrich, ref\# 1585), suberoylanilide hydroxamic acid (Sigma-Aldrich, ref\# SML0061) and 5-aza-2'-deoxycytidine (Sigma-Aldrich, ref\# A3656) were dissolved in DMSO.

\section{Cell culture and treatments}

The Bhas 42 cell line was obtained from Harlan Laboratories (Rossdorf, Germany). Bhas 42 cells are issued from the stable transfection of BALB/3T3/A31-1-1 cells with v-Ha-ras (Sasaki et al., 1988). Cells were maintained in a DMEM/HamF12 (1:1) culture medium $\left(\right.$ Gibco $^{\mathrm{TM}}$, Thermo Fisher Scientific) containing $1 \%$ antibiotic (Streptomycin and Penicillin, Gibco $^{\mathrm{TM}}$ ) and $5 \%$ fetal calf serum (Hyclone), at $37^{\circ} \mathrm{C}$ in a humid atmosphere with $5 \% \mathrm{CO}_{2}$. Cells were seeded at $15 \times 10^{7}$ cells $/ \mathrm{cm}^{2}$ and treated with particle concentrations of 15 and $25 \mu \mathrm{g} / \mathrm{cm}^{2}$ for Min-U-Sil ${ }^{\circledR} 5$ or 2 and $5 \mu \mathrm{g} / \mathrm{cm}^{2}$ for NM-203. The cell treatment schedule for the transformation assay is presented in Figure 1. Cell pellets were collected on day 6 (D6). Foci were isolated and cultured on day 21 (D21), and cell pellets were collected on day 29 (D29). 


\section{Western Blot analysis}

Total protein and histone extractions were performed as previously described (Seidel et al., 2014). Proteins were separated on polyacrylamide gradient gels (4-20\% Criterion ${ }^{\mathrm{TM}}$ TrisGlycine eXtended Stain-Free Protein Gel, BioRad) and transferred onto polyvinylidene difluoride (PVDF) membranes (BioRad). Membranes were incubated sequentially with blocking agent for $1 \mathrm{~h}$ at room temperature, then the primary antibody overnight at $4{ }^{\circ} \mathrm{C}$ and finally the secondary antibody for $1 \mathrm{~h}$ at room temperature (Table S2). The loading controls were $\beta$-actin and Coomassie blue staining (Merck) for total proteins and histones, respectively. Western Blot quantifications were performed using Image Lab (ChemiDoc ${ }^{\mathrm{TM}}$ system BioRad) and results were reported relative to the vehicle control.

\section{DNA methylation analysis by Elisa}

Genomic DNA (100 ng) was extracted from treated cells using the Wizard Genomic DNA kit (Promega). Global DNA methylation assays were performed according to the manufacturer's instructions (5-Methylcytosine DNA Elisa kit, Enzo ${ }^{\circledR}$ ). Percentages of 5-methylcytosine were calculated using a standard curve.

\section{Gene expression analysis by $R T-q P C R$}

Total RNA was extracted using the RNeasy Plus Mini Kit (Qiagen) according to the manufacturer's instructions. Total RNA (500 ng) was reverse-transcribed with iScript ${ }^{\mathrm{TM}}$ cDNA synthesis Kit (BioRad) following the manufacturer's protocol. Real-time PCR was performed with CFX96 Touch $^{\mathrm{TM}}$ (BioRad) in the presence of $\mathrm{iQ}^{\mathrm{TM}} \mathrm{SYBR}^{\circledR}$ Green Supermix (BioRad) and 2.5 $\mu \mathrm{M}$ of primers (Eurogentec; primer sequences are provided in Table S3). No template control was carried out on each PCR mixture. Amplification was performed as 
follows: 5 min at $95{ }^{\circ} \mathrm{C}, 35 \mathrm{x}\left(15 \mathrm{~s}\right.$ at $95^{\circ} \mathrm{C}$ and $60 \mathrm{~s}$ at $\left.60{ }^{\circ} \mathrm{C}\right)$. PCR results were analyzed using the $2^{-\Delta \Delta \mathrm{Cq}}$ method. The fold change of a target gene is expressed as treated cells with respect to vehicle control cells relative to four housekeeping genes ( $\beta$-actin, $\alpha$-tubulin, Gapdh and $T b p)$.

\section{Chromatin immunoprecipitation (ChIP)}

ChIP was performed as previously described (Seidel et al., 2014), using primers to target $c$ myc promoter, a negative region (neg) and the second exon of the $c$-myc gene (e2) (Eurogentec; primer sequences are provided in Table S3) and the following antibodies: RNA polymerase II, H3K4me3, H3K4Ac, H3K9Ac, H3K27Ac and 5-methylcytosine (Table S2).

\section{Statistical analyses}

Statistical analyses were performed using Stata 14.0 software. A logarithmic transformation was applied to the data. A mixed linear regression model was used to test the "dose" fixed effect, including a random effect termed "experience". When the "dose" effect was significant, a multiple comparisons post hoc test (with Bonferroni correction) was applied to test the difference between the control and different levels of doses. The statistical significance threshold was set at $5 \%$. 


\section{Results}

\section{Modulation of total DNA methylation}

We investigated the effect of particle treatment on total DNA methylation on D6. Regardless of the concentration used, Min-U-Sil@ 5 treatment resulted in a dramatic decrease (approx. $80 \%)$ in total DNA methylation (Figure 2A) $\left(p=0.015\right.$ for $15 \mu \mathrm{g} / \mathrm{cm}^{2}$ and $\mathrm{p}=0.001$ for 25 $\mu \mathrm{g} / \mathrm{cm}^{2}$ ). As expected, 5-aza-2'-deoxycytidine treatment also decreased the 5-methylcytosine content $(\mathrm{p}<0.001)$. In contrast, NM-203 did not affect total DNA methylation under any of the conditions.

Under our experimental conditions, Min-U-Sil® 5 treatment $\left(15\right.$ and $\left.25 \mu \mathrm{g} / \mathrm{cm}^{2}\right)$ increased DNMT3a and 3b protein levels (Figure 2B). Whereas the DNMT1 protein level remained unchanged after treatment with $15 \mu \mathrm{g} / \mathrm{cm}^{2}$ of Min-U-Sil ${ }^{\circledR} 5$, it even decreased after treatment with $25 \mu \mathrm{g} / \mathrm{cm}^{2}$. Treatment with NM-203 did not affect the levels of the three DNMTs at any of the concentrations tested.

\section{Effect of Min-U-Sil@ 5 on HDAC protein levels}

Cellular extracts of Min-U-Sil@ 5-treated cells taken on D6 contained an increased amount of the HDAC2 protein, while the level of HDAC1 decreased significantly and the level of the HDAC3 protein remained unchanged (Figure 3A). Treatments with both concentrations of Min-U-Sil® 5 reduced the HDAC6 protein level by $50 \%$. Despite the modulation of the HDAC protein level after Min-U-Sil ${ }^{\circledR} 5$ treatment, a moderate but significant increase in histone $\mathrm{H} 4$ acetylation was observed while the level of histone $\mathrm{H} 3$ acetylation remained

unchanged (Figure 3B). The four HDACs tested remained unchanged under NM-203 treatment and no modification of histone acetylation was observed for histones H3 or H4. 


\section{Induction of c-myc expression and modulation of histone modifications on the c-myc}

\section{promoter}

We analyzed the expression of $c-m y c$ after Min-U-Sil® 5 and NM-203 treatments. Treatment by both particles induced high c-Myc protein levels (Figure 4A). 6-fold increase was observed after treatment with $15 \mu \mathrm{g} / \mathrm{cm}^{2}$ and $25 \mu \mathrm{g} / \mathrm{cm}^{2}$ of Min-U-Sil® 5, while treatment with NM-203 increased c-Myc protein levels by 2.5 -fold and 11 -fold at $2 \mu \mathrm{g} / \mathrm{cm}^{2}$ and $5 \mu \mathrm{g} / \mathrm{cm}^{2}$, respectively. We observed 7-fold and 11-fold increases in the $c$-myc mRNA level after treatment with $15 \mu \mathrm{g} / \mathrm{cm}^{2}(\mathrm{p}<0.001)$ and $25 \mu \mathrm{g} / \mathrm{cm}^{2}(\mathrm{p}<0.001)$ of Min-U-Sil@ 5, respectively (Figure 4B). Treatment with the lowest concentration of NM-203 $\left(2 \mu \mathrm{g} / \mathrm{cm}^{2}\right)$ did not modulate $c$-myc mRNA, whereas treatment with the highest concentration $\left(5 \mu \mathrm{g} / \mathrm{cm}^{2}\right)$ resulted in a significant (4-fold) increase $(\mathrm{p}<0.001)$. In addition, we observed a decrease of the c-Myc target gene collA2 mRNA after treatment by both concentration of Min-U-Sil® 5 (70\% and $80 \%$ decrease for $15 \mu \mathrm{g} / \mathrm{cm}^{2}$ and $25 \mu \mathrm{g} / \mathrm{cm}^{2}$, respectively, $\mathrm{p}<0.005$, Figure $4 \mathrm{C}$ ). Treatment with the lowest concentration of NM-203 slightly decreased collA2 expression (20\%), whereas the highest concentration decreased by half its mRNA level $(\mathrm{p}<0.001)$. In order to study the effect of c-Myc overexpression, we analyzed also the cell cycle progression. Treatment with both particle increased the number of cells in $\mathrm{S}$ phase in a dosedependent manner $(\mathrm{p}<0.001$, Figure S1). NM-203 treatment also increased the cell population in G2/M phase and decreased it in G0/G1 phase.

The $c$-myc gene is mainly transcribed from two promoters, known as $\mathrm{P} 1$ and $\mathrm{P} 2$, of which $\mathrm{P} 2$ is the major one (Figure 5A). Chromatin immunoprecipitation showed a significant increase in the level of RNA polymerase II at both promoters after Min-U-Sil® 5 treatment (Figure 5B) $(\mathrm{p}<0.001)$. This was consistent with the increased expression of $c-m y c$ and the enrichment of RNA polymerase II on its promoters, we also found an enrichment of this protein in exon 2 of the $c-m y c$ gene after treatment with Min-U-Sil@ 5 ( $\mathrm{p}=0.002$ for 15 
$\mu \mathrm{g} / \mathrm{cm}^{2}$ and $\mathrm{p}=0.04$ for $25 \mu \mathrm{g} / \mathrm{cm}^{2}$ ). This indicates that increased binding of RNA polymerase II to the $c-m y c$ promoters is associated with a higher transcription of the gene. Furthermore, Min-U-Sil ${ }^{\circledR} 5$ treatment significantly increased marks of actively transcribed chromatin, such as acetylated or trimethylated histone $\mathrm{H} 3$ lysine $4(\mathrm{H} 3 \mathrm{~K} 4 \mathrm{Ac}, \mathrm{H} 3 \mathrm{~K} 4 \mathrm{me} 3)(\mathrm{p}=$ 0.009 for $15 \mu \mathrm{g} / \mathrm{cm}^{2}$ for H3K4Ac $-\mathrm{p}<0.001$ for $25 \mu \mathrm{g} / \mathrm{cm}^{2}$ for H3K4Ac and for both dose for $\mathrm{H} 3 \mathrm{~K} 4 \mathrm{me} 3$ ), acetylated histone $\mathrm{H} 3$ lysine 9 (H3K9Ac) and acetylated histone H3 lysine 27 (H3K27Ac), on the P1 promoter (Figure 5C) $\left(\mathrm{p}<0.001\right.$ for $25 \mu \mathrm{g} / \mathrm{cm}^{2}$ for $\mathrm{H} 3 \mathrm{~K} 9 \mathrm{Ac}$ and $\mathrm{H} 3 \mathrm{~K} 27 \mathrm{Ac}-\mathrm{p}=0.04$ for $15 \mu \mathrm{g} / \mathrm{cm}^{2}$ for $\left.\mathrm{H} 3 \mathrm{~K} 9 \mathrm{Ac}\right)$. Promoter enrichment after NM-203 treatment was analyzed with the highest concentration as the lowest concentration had no effect on the $c-m y c$ mRNA level. NM-203 treatment increased the level of RNA polymerase II only at the P1 promoter $(\mathrm{p}<0.001)$ concomitantly with enrichment of all of the histone active marks examined $(\mathrm{p}<0.001)$. Neither Min-U-Sil@ 5 nor NM-203 treatments modulated 5-methylcytosine levels on P1 promoter.

\section{Reversion of molecular mechanisms in isolated foci}

Isolated foci were amplified and collected in order to study the effects of repeated treatments with Min-U-Sil® 5 and NM-203 particles (treatments on D4, D7 and D10, figure 1). As shown in figure 6, almost all parameters modulated on D6 were restored to basal levels on D29. Indeed, in isolated foci DNA methylation as well as HDAC2 and 6 protein levels were similar to those of control cells (Figure 6). However, on D29 we still observed an increase of DNMT3a and $3 b$ protein levels upon Min-U-Sil@ 5 treatment. Western Blot analysis of the other DNMT and HDAC did not reveal any changes in their protein levels (Figure S2). Total and acetylated histones $\mathrm{H} 3$ and $\mathrm{H} 4$ levels were not affected by repeated treatments (Figure S2). A moderate but significant increase of $c-m y c$ mRNA was observed only after treatment by the highest concentration of Min-U-Sil ${ }^{\circledR} 5(\mathrm{p}=0.035$, Figure 6C). In agreement with $c$ - 
myc RNA level, its protein level remained higher than control cells after repeated treatments by the highest concentration of Min-U-Sil® 5 (Figure 6D). In isolated transformed foci after NM-203 treatment, $c$-myc mRNA and protein levels were similar to the control cells. 


\section{Discussion}

The increasing use of nanomaterials makes the study of their impact on human health a necessity. Evaluation of the epigenetic effects of particles is a recent approach in nanotoxicology, and several recent studies support the involvement of epigenetic modulation in carcinogenicity induced by nanomaterial (Belinsky et al., 2002, Gong et al., 2010, Patil et al., 2016).

Accordingly, we investigated the effect of a nano-silica particle, NM-203, on Bhas 42 cells. In parallel, we also tested a crystalline silica microparticle, Min-U-Sil ${ }$ 5, known for its transforming and carcinogenic properties (Darne et al., 2016). In a previous work, we observed that both particles induced Bhas 42 cell transformation in the promotion assay (Fontana et al., In press). Several studies reported an increased production of ROS after particle treatment and suggested that increased oxidative stress could be one of the causes of cellular transformation (Carpenter et al., 2011, Yang et al., 2007, Zhou and Ryeom, 2014). In addition, transforming effects of silica particles have previously been associated with the production of ROS (Elias et al., 2000, Elias et al., 2006). Under our experimental conditions, we did not observe any increase in ROS production, which may suggest the lack of involvement of this mechanism in Min-U-Sil® 5- or NM-203-induced Bhas 42 cell transformation (data not shown).

Global DNA hypomethylation could result in aberrant expression of many important (onco)genes as well as in the reactivation of mobile elements and consequently in genome instability that could lead to cellular transformation (Gama-Sosa et al., 1983). In the Bhas 42 cell model, while Min-U-Sil@ 5 treatment was found to decrease global DNA methylation, treatment of Bhas 42 cells with NM-203 did not affect it. Gong et al. (2010) observed that amorphous silica nanoparticle treatment of human HaCaT cells decreased global DNA 
methylation, suggesting that modification of the methylation status of DNA after such treatment could be cell-line-specific. Other particles, such as titanium dioxide and zinc oxide, also decreased DNA methylation and this was accompanied by the induction of oxidative stress, which is known to be associated with gene hypomethylation (Patil et al., 2016). Despite the absence of ROS overproduction in Min-U-Sil ${ }^{\circledR} 5$ treated cells, the strong DNA hypomethylation suggests that mechanisms other than those controlled by ROS could be involved. Three main enzymes are considered responsible for DNA methylation - a maintenance enzyme, DNMT1, and the de novo enzymes, DNMT3a and DNMT3b - and several studies suggest an increase in DNMT expression in cancer cells (Robertson et al., 1999). While the treatment with NM-203 particles did not modulate the DNMT protein level, Min-U-Sil® 5 treatment decreased the DNMT1 protein level at the highest concentration tested. This observation might suggest a link with DNA hypomethylation. Recent studies suggest that DNA hypomethylation after particle treatment is related to a decrease in the DNMT mRNA, protein levels, or enzyme activity (Gong et al., 2010, Patil et al., 2016). At the lowest concentration of Min-U-Sil® 5 tested, the observed DNA hypomethylation could be a consequence of reduced DNMT1 recruitment or reduced availability of DNMT1 partners, such as UHRF1 and PCNA, during mitosis (Liu et al., 2013). Under our experimental model, we observed that cell treatment with both concentrations of Min-U-Sil® 5 induced de novo DNMT3a and DNMT3b protein levels that might induce DNA methylation only at specific loci, and thus participate in cellular transformation. Indeed, the majority of tumor cells exhibit local hypermethylation that leads to aberrant gene silencing, including the silencing of tumor suppressor genes (Seidel et al., 2012).

Other epigenetic modifications, such as histone acetylation regulated by HDAC enzymes that play an active role in epigenetic regulation of gene expression, could also be involved in cell transformation (Wilting and Dannenberg, 2012). In our model, only the 
treatment with the highest concentration of Min-U-Sil@ 5 induced an increase in histone H4 acetylation. However, treatment with Min-U-Sil® 5 decreased the levels of HDAC1 and HDAC6 proteins and increased the level of HDAC2. Down-regulation of HDAC6 could be linked to tumor development through modulation of the acetylation status of various cytoplasmic proteins (Seidel et al., 2015). An increase in HDAC2 could result in an HDAC1 decrease, as demonstrated previously (Winter et al., 2013, Yamaguchi et al., 2010). Modulation of HDAC1, HDAC2 and HDAC3 protein levels should alter the acetylation status of histones on specific sequences, whereas disruption of the HDAC6 protein level should modulate the activity of non-histone proteins.

Taken together, these data indicate that changes in global epigenetic modifications, as well as changes in DNMT and HDAC protein levels, are not directly related to the transformation of Bhas 42 cells induced by Min-U-Sil® 5 and NM-203 treatment. Nevertheless, changes in expression of specific genes could be an important parameter in cell transformation. It is well known that the $c-m y c$ oncogene is involved in cell transformation (Flores et al., 2004). We therefore investigated the expression of the $c$-myc oncogene and observed that both Min-U-Sil ${ }^{\circledR} 5$ and NM-203 treatments increased it. The treatment with the lowest dose of NM-203 increased c-Myc at the protein level but not at the mRNA level, suggesting a possible effect on protein stability. It is well known that the c-Myc protein has a short half-life (around 30 minutes) that is regulated by a number of different mechanisms (Facchini et al., 1997). Treatment with the highest concentration of NM-203 or with Min-USil@ 5 increased both protein and mRNA levels, suggesting the involvement of additional regulation mechanisms of protein stability. Indeed, we observed an increase of RNA polymerase II occupancy on $c-m y c$ promoters, suggesting an increase in transcription initiation and mRNA synthesis. The $c-m y c$ gene is transcribed from four different promoters (from 5' to 3' P0, P1, P2, P3), with P2 considered to be the main promoter (Hu et al., 2007, 
Luo and Krause, 1994). Our results revealed that NM-203 treatment triggers only the P1 promoter whereas treatment with Min-U-Sil® 5 induces transcription from $\mathrm{P} 1$ and $\mathrm{P} 2$ promoters. This could explain the smaller increase in mRNA level observed after treatment with NM-203 particles compared to exposure to Min-U-Sil® 5 particles. The observed transcriptional induction was accompanied by enrichment in chromatin active marks on the P1 promoter, indicating that the particle treatments induced an open chromatin state in this region. Unchanged in 5-methylcytosine on P1 promoter suggests that the methylation status of $c$-myc promoter was already in favor for transcriptional activation. As a consequence of cMyc overexpression we observed the transcriptional repression of collA2 gene as previously described in a mice cell model and could be linked to cell transformation (Hatamochi et al., 1991, Yang et al., 1991). Moreover, we observed that both particle treatments induced an increase of cells in S phase, whereas NM-203 treatment also induced the number of cells in G2/M phase. Cell cycle progression is controlled by several checkpoints in order to ensure a faithful replication and division (Visconti et al., 2016). Cell cycle arrest could allow cells to repair damages or induce cell death. Since, cancer cells are often defective in some checkpoint mechanisms, we hypothesized that particle treatments could induce replication stress, a potential consequence of c-Myc overexpression, between D4 to D6 leading to an arrest of cell cycle progression in S phase (Visconti et al., 2016, Zeman and Cimprich, 2014). DNA damages were probably not involved in S phase arrest, since we did not observe strand breaks upon Min-U-Sil@ 5 nor NM-203 treatments in comet assay (data not shown). We could suggest that some cells are able to escape cell cycle controls and that may lead to foci transformation.

Study of epigenetic modifications and c-Myc expression in transformed foci revealed a global reversion of the alterations described on D6. Indeed, except DNMT3a and 3b protein levels and the level of c-Myc mRNA and protein after treatment by the highest concentration 
of Min-U-Sil® 5, none of the parameters analyzed on D6 were modulated on D29 in isolated transformed foci. These results suggest that epigenetic changes and c-Myc overexpression are involved in the early stage of silica-induced cell transformation as suggested by Chen et al (2017) in gastric neoplasia (Chen et al., 2017).

\section{Conclusion}

The need to characterize the toxicological properties of nanomaterials and the mechanisms responsible for their pathogenicity are important. However, conventional tests of carcinogenicity in animals are time consuming and costly to address the very wide variety of particles that exist. In this context, in vitro cell transformation tests are valuable first-line screening tools for assessing the carcinogenic potential of particles. Epigenetic mechanisms are involved in cell transformation, and analysis of epigenetic changes during cancer cell development appears to be an important parameter in the early stages of disease development. Our study highlighted the fact that global epigenetic changes alone may not be sufficient for identifying any modulation of epigenetic marks caused by nanomaterial exposure, and we therefore suggest analyzing specific genome loci. Even though both tested particles induced cell transformation, the mechanisms driving this process might differ from one particle to another. This work has revealed that a number of different mechanisms might lead to cell transformation induced by silica particles, and evaluation of other specific genes could lead us to a better understanding of these mechanisms. 


\section{Acknowledgments}

The authors gratefully acknowledge Sylvie Sébillaud and Mylène Lorcin for cell cycle analysis.

\section{Conflict of interest}

The authors report no conflict of interests. 


\section{References}

Bakand S, Hayes A. 2016. Toxicological Considerations, Toxicity Assessment, and Risk Management of Inhaled Nanoparticles. Int J Mol Sci 17.

Belinsky SA, Snow SS, Nikula KJ, Finch GL, Tellez CS, Palmisano WA. 2002. Aberrant $\mathrm{CpG}$ island methylation of the p16(INK4a) and estrogen receptor genes in rat lung tumors induced by particulate carcinogens. Carcinogenesis 23:335-9.

Bhattacharjee P, Paul S. 2016. Risk of occupational exposure to asbestos, silicon and arsenic on pulmonary disorders: Understanding the genetic-epigenetic interplay and future prospects. Environ Res 147:425-34.

Bradbury CA, Khanim FL, Hayden R, Bunce CM, White DA, Drayson MT, Craddock C, Turner BM. 2005. Histone deacetylases in acute myeloid leukaemia show a distinctive pattern of expression that changes selectively in response to deacetylase inhibitors. Leukemia 19:1751-9.

Carpenter RL, Jiang Y, Jing Y, He J, Rojanasakul Y, Liu LZ, Jiang BH. 2011. Arsenite induces cell transformation by reactive oxygen species, AKT, ERK1/2, and p70S6K1. Biochem Biophys Res Commun 414:533-8.

Chen Z, Soutto M, Rahman B, Fazili MW, Peng D, Blanca Piazuelo M, Chen H, Kay Washington M, Shyr Y, El-Rifai W. 2017. Integrated expression analysis identifies transcription networks in mouse and human gastric neoplasia. Genes Chromosomes Cancer 56:535-547.

Darne C, Coulais C, Terzetti F, Fontana C, Binet S, Gate L, Guichard Y. 2016. In vitro comet and micronucleus assays do not predict morphological transforming effects of silica particles in Syrian Hamster Embryo cells. Mutat Res Genet Toxicol Environ Mutagen 796:23-33. 
Deshpande A, Narayanan PK, Lehnert BE. 2002. Silica-induced generation of extracellular factor(s) increases reactive oxygen species in human bronchial epithelial cells. Toxicol Sci 67:275-83.

Di Cristo L, Movia D, Bianchi MG, Allegri M, Mohamed BM, Bell AP, Moore C, Pinelli S, Rasmussen K, Riego-Sintes J, Prina-Mello A, Bussolati O, Bergamaschi E. 2016. Proinflammatory Effects of Pyrogenic and Precipitated Amorphous Silica Nanoparticles in Innate Immunity Cells. Toxicol Sci 150:40-53.

Elias Z, Poirot O, Daniere MC, Terzetti F, Marande AM, Dzwigaj S, Pezerat H, Fenoglio I, Fubini B. 2000. Cytotoxic and transforming effects of silica particles with different surface properties in Syrian hamster embryo (SHE) cells. Toxicol In Vitro 14:409-22. Elias Z, Poirot O, Fenoglio I, Ghiazza M, Daniere MC, Terzetti F, Darne C, Coulais C, Matekovits I, Fubini B. 2006. Surface reactivity, cytotoxic, and morphological transforming effects of diatomaceous Earth products in Syrian hamster embryo cells. Toxicol Sci 91:510-20.

Facchini LM, Chen S, Marhin WW, Lear JN, Penn LZ. 1997. The Myc negative autoregulation mechanism requires Myc-Max association and involves the c-myc P2 minimal promoter. Mol Cell Biol 17:100-14.

Flores I, Murphy DJ, Swigart LB, Knies U, Evan GI. 2004. Defining the temporal requirements for Myc in the progression and maintenance of skin neoplasia. Oncogene 23:5923-30.

Fontana C, Kirsch A, Seidel C, Marpeaux L, Darne C, Gaté L, Remy A, Guichard Y. In press. In vitro cell transformation induced by synthetic amorphous silica nanoparticles. Mutation Research - Genetic Toxicology and Environmental Mutagenesis. 
Gama-Sosa MA, Slagel VA, Trewyn RW, Oxenhandler R, Kuo KC, Gehrke CW, Ehrlich M. 1983. The 5-methylcytosine content of DNA from human tumors. Nucleic Acids Res 11:6883-94.

Gartel AL, Ye X, Goufman E, Shianov P, Hay N, Najmabadi F, Tyner AL. 2001. Myc represses the p21(WAF1/CIP1) promoter and interacts with Sp1/Sp3. Proc Natl Acad Sci U S A 98:4510-5.

Geiman TM, Robertson KD. 2002. Chromatin remodeling, histone modifications, and DNA methylation-how does it all fit together? J Cell Biochem 87:117-25.

Gong C, Tao G, Yang L, Liu J, Liu Q, Li W, Zhuang Z. 2012. Methylation of PARP-1 promoter involved in the regulation of nano-SiO2-induced decrease of PARP-1 mRNA expression. Toxicol Lett 209:264-9.

Gong C, Tao G, Yang L, Liu J, Liu Q, Zhuang Z. 2010. SiO(2) nanoparticles induce global genomic hypomethylation in HaCaT cells. Biochem Biophys Res Commun 397:397400.

Guichard Y, Fontana C, Chavinier E, Terzetti F, Gate L, Binet S, Darne C. 2016. Cytotoxic and genotoxic evaluation of different synthetic amorphous silica nanomaterials in the V79 cell line. Toxicol Ind Health 32:1639-50.

Hatamochi A, Ono M, Ueki H, Namba M. 1991. Regulation of collagen gene expression by transformed human fibroblasts: decreased type I and type III collagen RNA transcription. J Invest Dermatol 96:473-7.

Hu HM, Kanda K, Zhang L, Boxer LM. 2007. Activation of the c-myc p1 promoter in Burkitt's lymphoma by the hs3 immunoglobulin heavy-chain gene enhancer. Leukemia 21:747-53. 
Johnston CJ, Driscoll KE, Finkelstein JN, Baggs R, O'reilly MA, Carter J, Gelein R, Oberdorster G. 2000. Pulmonary chemokine and mutagenic responses in rats after subchronic inhalation of amorphous and crystalline silica. Toxicol Sci 56:405-13.

Knaapen AM, Albrecht C, Becker A, Hohr D, Winzer A, Haenen GR, Borm PJ, Schins RP. 2002. DNA damage in lung epithelial cells isolated from rats exposed to quartz: role of surface reactivity and neutrophilic inflammation. Carcinogenesis 23:1111-20.

Koenig A, Linhart T, Schlengemann K, Reutlinger K, Wegele J, Adler G, Singh G, Hofmann L, Kunsch S, Buch T, Schafer E, Gress TM, Fernandez-Zapico ME, Ellenrieder V. 2010. NFAT-induced histone acetylation relay switch promotes c-Myc-dependent growth in pancreatic cancer cells. Gastroenterology 138:1189-99 e1-2.

Lin CY, Loven J, Rahl PB, Paranal RM, Burge CB, Bradner JE, Lee TI, Young RA. 2012. Transcriptional amplification in tumor cells with elevated c-Myc. Cell 151:56-67.

Liu X, Gao Q, Li P, Zhao Q, Zhang J, Li J, Koseki H, Wong J. 2013. UHRF1 targets DNMT1 for DNA methylation through cooperative binding of hemi-methylated DNA and methylated H3K9. Nat Commun 4:1563.

Lu X, Miousse IR, Pirela SV, Melnyk S, Koturbash I, Demokritou P. 2016. Short-term exposure to engineered nanomaterials affects cellular epigenome. Nanotoxicology $10: 140-50$.

Luo Y, Krause MO. 1994. Changes in promoter utilization in human and mouse c-myc genes upon transformation induction in temperature-sensitive cell lines. J Cell Physiol 160:303-15.

Mischler SE, Cauda EG, Di Giuseppe M, Mcwilliams LJ, St Croix C, Sun M, Franks J, Ortiz LA. 2016. Differential activation of RAW 264.7 macrophages by size-segregated crystalline silica. J Occup Med Toxicol 11:57. 
Monographs I. 1997. Silica, some silicates, coal dust and para-Aramdi fibrils, IARC

Monographs on the Evaluation of Carcinogenic Risks to Humans. 68.

Murugadoss S, Lison D, Godderis L, Van Den Brule S, Mast J, Brassinne F, Sebaihi N, Hoet PH. 2017. Toxicology of silica nanoparticles: an update. Arch Toxicol.

O'connell BC, Cheung AF, Simkevich CP, Tam W, Ren X, Mateyak MK, Sedivy JM. 2003. A large scale genetic analysis of c-Myc-regulated gene expression patterns. J Biol Chem 278:12563-73.

Oecd. 2016. OECD, Guidance Document On the In Vitro Bhas 42 Cell Transformation Assay Series on Testing \& Assessment No. 231. ENV/JM/MONO (2016)1.

Patil NA, Gade WN, Deobagkar DD. 2016. Epigenetic modulation upon exposure of lung fibroblasts to $\mathrm{TiO} 2$ and $\mathrm{ZnO}$ nanoparticles: alterations in DNA methylation. Int $\mathrm{J}$ Nanomedicine 11:4509-4519.

Pelengaris S, Khan M, Evan G. 2002. c-MYC: more than just a matter of life and death. Nat Rev Cancer 2:764-76.

Rasmussen K, Mech A, Mast J, De Temmerman PJ, Van Doren E, Waegeneers N, Van Steen F, Pizzolon JC, De Temmerman L, Jensen KA. 2013. Synthetic amorphous silicon dioxide (NM-200, NM-201, NM-202, NM-203, NM-204). Characterisation and physico-chemical properties. JRC repository: NM-series of representative manufactured banomaterials. Office of the European Union 200 p.

Robertson KD, Uzvolgyi E, Liang G, Talmadge C, Sumegi J, Gonzales FA, Jones PA. 1999. The human DNA methyltransferases (DNMTs) 1, 3a and 3b: coordinate mRNA expression in normal tissues and overexpression in tumors. Nucleic Acids Res 27:2291-8.

Saffiotti U, Ahmed N. 1995. Neoplastic transformation by quartz in the BALB/3T3/A31-1-1 cell line and the effects of associated minerals. Teratog Carcinog Mutagen 15:339-56. 
Sasaki K, Mizusawa H, Ishidate M. 1988. Isolation and characterization of ras-transfected BALB/3T3 clone showing morphological transformation by 12-O-tetradecanoylphorbol-13-acetate. Jpn J Cancer Res 79:921-30.

Seidel C, Schnekenburger M, Dicato M, Diederich M. 2014. Antiproliferative and proapoptotic activities of 4-hydroxybenzoic acid-based inhibitors of histone deacetylases. Cancer Lett 343:134-46.

Seidel C, Schnekenburger M, Dicato M, Diederich M. 2015. Histone deacetylase 6 in health and disease. Epigenomics 7:103-18.

Stoccoro A, Karlsson HL, Coppede F, Migliore L. 2013. Epigenetic effects of nano-sized materials. Toxicology 313:3-14.

Uboldi C, Giudetti G, Broggi F, Gilliland D, Ponti J, Rossi F. 2012. Amorphous silica nanoparticles do not induce cytotoxicity, cell transformation or genotoxicity in Balb/3T3 mouse fibroblasts. Mutat Res 745:11-20.

Visconti R, Della Monica R, Grieco D. 2016. Cell cycle checkpoint in cancer: a therapeutically targetable double-edged sword. J Exp Clin Cancer Res 35:153.

Weber M, Davies JJ, Wittig D, Oakeley EJ, Haase M, Lam WL, Schubeler D. 2005. Chromosome-wide and promoter-specific analyses identify sites of differential DNA methylation in normal and transformed human cells. Nat Genet 37:853-62.

Wilting RH, Dannenberg JH. 2012. Epigenetic mechanisms in tumorigenesis, tumor cell heterogeneity and drug resistance. Drug Resist Updat 15:21-38.

Winter M, Moser MA, Meunier D, Fischer C, Machat G, Mattes K, Lichtenberger BM, Brunmeir R, Weissmann S, Murko C, Humer C, Meischel T, Brosch G, Matthias P, Sibilia M, Seiser C. 2013. Divergent roles of HDAC1 and HDAC2 in the regulation of epidermal development and tumorigenesis. EMBO J 32:3176-91. 
Yamaguchi T, Cubizolles F, Zhang Y, Reichert N, Kohler H, Seiser C, Matthias P. 2010. Histone deacetylases 1 and 2 act in concert to promote the G1-to-S progression. Genes Dev 24:455-69.

Yang BS, Geddes TJ, Pogulis RJ, De Crombrugghe B, Freytag SO. 1991. Transcriptional suppression of cellular gene expression by c-Myc. Mol Cell Biol 11:2291-5.

Yang S, Misner BJ, Chiu RJ, Meyskens FL, Jr. 2007. Redox effector factor-1, combined with reactive oxygen species, plays an important role in the transformation of JB6 cells. Carcinogenesis 28:2382-90.

Zeman MK, Cimprich KA. 2014. Causes and consequences of replication stress. Nat Cell Biol 16:2-9.

Zhou AY, Ryeom S. 2014. Cyclosporin A promotes tumor angiogenesis in a calcineurinindependent manner by increasing mitochondrial reactive oxygen species. Mol Cancer Res 12:1663-76. 


\section{Titles and legends of figures}

Figure 1: Treatment of Bhas 42 cells by Min-U-Sil ${ }^{\circ} 5$ and NM-203.

Cells were seeded on D0, treated on D4, D7 and D10 (red arrows) and the medium was changed on D14. Cell pellets were collected on D6. Giemsa staining was carried out on foci on D21 and foci were isolated. Selected cells were cultured and cell pellets were collected on D29.

\section{Figure 2: Micro-silica particle treatment affects DNA methylation and DNMTs.}

(A) Global DNA methylation on D6 was analyzed by Elisa test on the total genomic DNA of treated cells by Min-U-Sil® 5 or NM-203 at the indicated concentrations. The positive controls were cells treated for 72 hours with $0.05 \mu \mathrm{M}$ 5-aza-2'-deoxycytidine (+). Histograms correspond to the mean \pm SD of three independent experiments. (B) DNMT1, 3a and 3b protein levels were determined by Western Blot after cell treatment with Min-U-Sil® 5 or NM-203 at the indicated concentrations. The blots are representative of three independent experiments and the quantifications are indicated. $\beta$-actin was used as a loading control. * and $* * *$ indicate $\mathrm{p}<0.05$ and $\mathrm{p}<0.005$, respectively, versus untreated cells in a Bonferroni multiple comparison tests.

\section{Figure 3: Modulation of HDAC protein levels and histone acetylation.}

Western Blot analyses of (A) HDAC1, HDAC2, HDAC3 and HDAC6 and (B) acetylated and total histone H3 and H4 were carried out on D6 after treatment with Min-U-Sil@ 5 or NM203 at the indicated concentrations. The positive controls were cells treated for 24 hours with $2 \mu \mathrm{M}$ of suberoylanilide hydroxamic acid $(+)$. The blots are representative of three 
independent experiments and the quantifications are indicated. $\beta$-actin and Coomassie Blue staining were used as loading controls for total proteins and histones, respectively.

\section{Figure 4: Silica particle treatment increases $c$-myc expression.}

(A) Western Blot analyses of the c-Myc protein level were performed after Min-U-Sil® 5 and NM-203 treatment at the indicated concentrations. Blots are representative of three independent experiments and the quantifications are indicated. $\beta$-actin was used as a loading control. (B) c-myc expression and (C) collA2 expression were examined by RT-qPCR on D6 after treatment with Min-U-Sil@ 5 and NM-203. $\beta$-actin, $\alpha$-tubulin, Gapdh and Tbp were used as housekeeping genes. $* * *$ indicates $\mathrm{p}<0.005$ versus untreated cells in a Bonferroni multiple comparison tests.

Figure 5: Transcriptional up-regulation of $c$-myc through modulation of epigenetic marks on its promoter.

(A) Schematic representation of $c$-myc promoters. The $\mathrm{CpG}$ island is represented by open circles, and transcription start sites are indicated as well as the primers used for ChIP analysis (red half-arrows). (B) RNA polymerase II enrichment on promoters P1 and P2 as well as on exon 2 (e2), and a negative region (neg) was analyzed on D6 after treatment by Min-USil® 5 and NM-203. (C) Acetylated histone H3 lysine 4 (H3K4Ac), trimethylated histone H3 lysine 4 (H3K4me3), acetylated histone H3 lysine 9 (H3K9Ac), acetylated histone H3 lysine 27 (H3K27Ac) and 5-methylcytosine (5-mC) enrichment were carried out after Min-USil® 5 or NM-203 treatment on the P1 promoter. Histograms correspond to the mean \pm SD of three independent experiments. *, ** and $* * *$ indicate $\mathrm{p}<0.05, \mathrm{p}<0.01$ and $\mathrm{p}<0.005$, respectively, versus control cells, in a Bonferroni multiple comparison tests. 


\section{Figure 6: Reversion of molecular mechanisms in isolated foci.}

(A) Global DNA methylation on D29 was analyzed by Elisa test on the total genomic DNA of cells treated by Min-U-Sil® 5 or NM-203 at the indicated concentrations. The positive controls were cells treated for 72 hours with $0.05 \mu \mathrm{M}$ 5-aza-2'-deoxycytidine (+). Histograms correspond to the mean \pm SD of three independent experiments. (B) DNMT3a and 3b, HDAC2 and 6 protein levels were determined by Western Blot after cell treatment with MinU-Sil® 5 or NM-203 at the indicated concentrations. (C) $c-m y c$ expression was analyzed by RT-qPCR on D29 after treatment with Min-U-Sil® 5 and NM-203. $\beta$-actin, $\alpha$-tubulin, Gapdh and Tbp were used as housekeeping genes. (D) Western Blot analyses of the c-Myc protein level on D29 were performed after Min-U-Sil® 5 and NM-203 treatment at the indicated concentrations. The blots are representative of three independent experiments and the quantifications are indicated. $\beta$-actin was used as a loading control. * and *** indicate $\mathrm{p}<0.05$ and $\mathrm{p}<0.005$, respectively, versus untreated cells, in a Bonferroni multiple comparison tests. 
Fig. 1

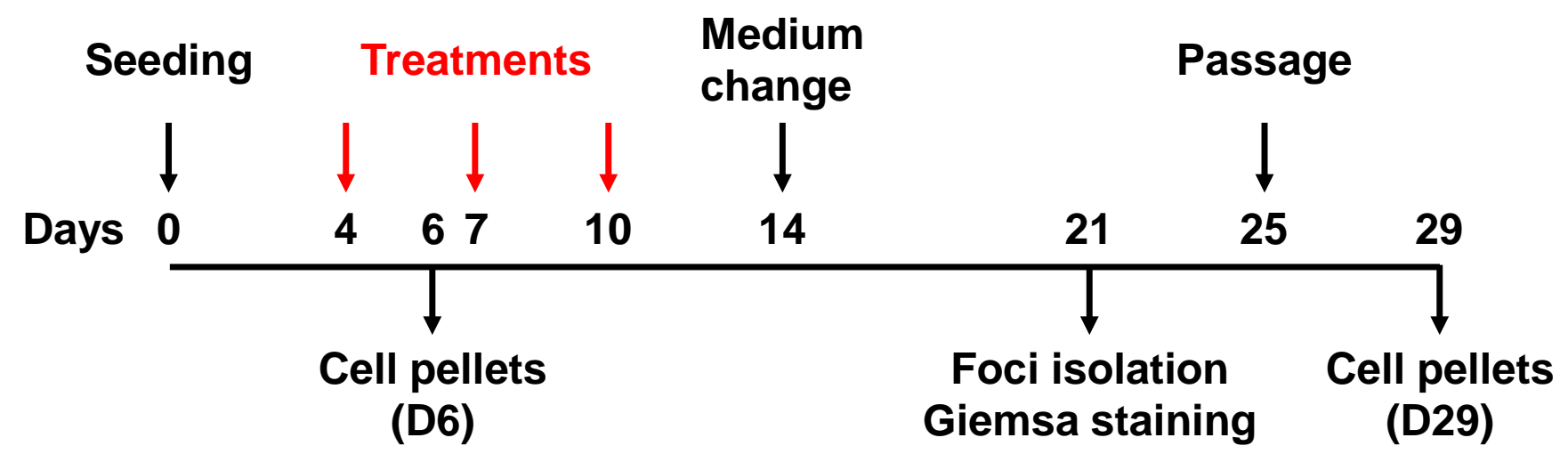


Fig. 2

A

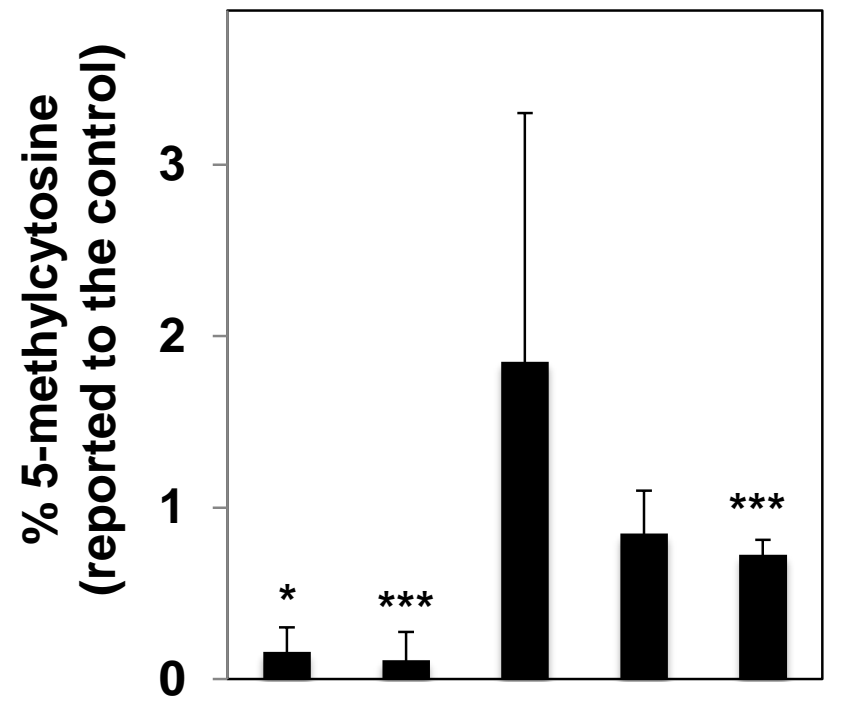

$\mu \mathrm{g} / \mathrm{cm}^{2} \underset{\text { Min-U-Sil }}{\frac{15}{\mathrm{NM}-203}} \stackrel{2 \quad 5}{\text { N }}+$

B

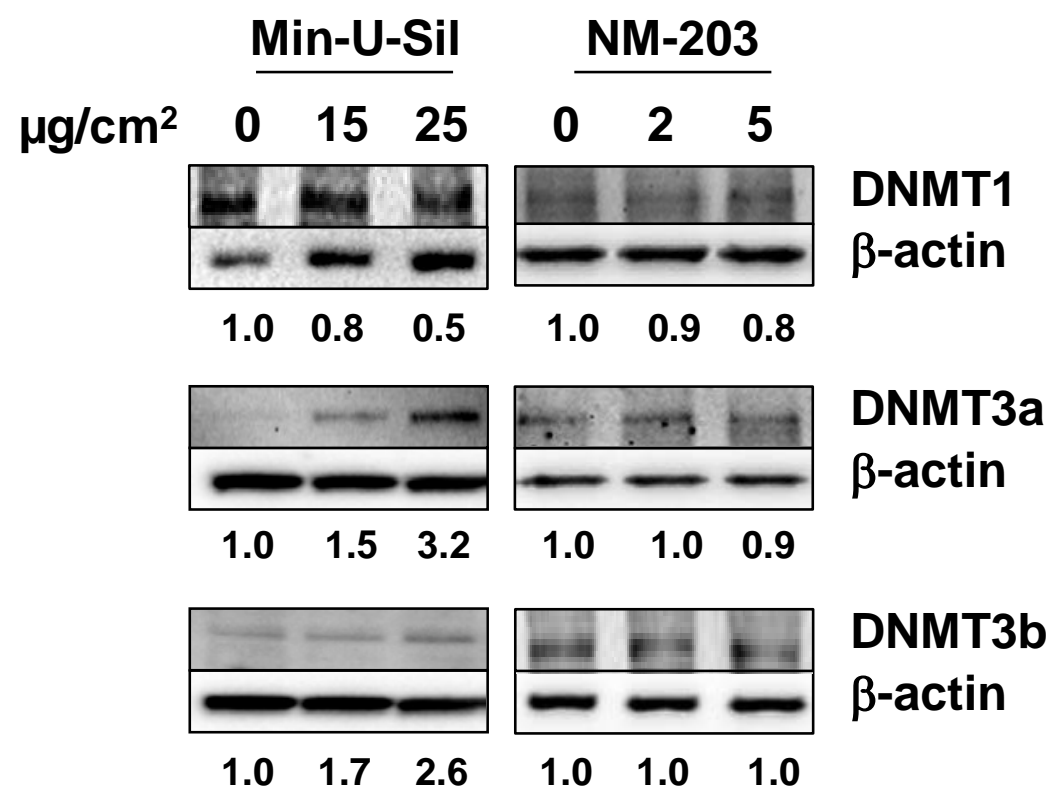


A

\section{Min-U-Sil NM-203}

$\begin{array}{lllllll}\mu \mathrm{g} / \mathrm{cm}^{2} & 0 & 15 & 25 & 0 & 2 & 5\end{array}$
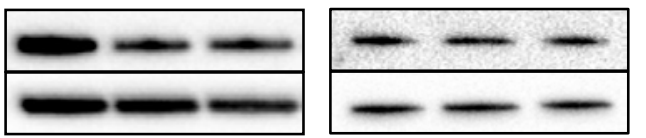

HDAC1

$\begin{array}{llllll}1.0 & 0.5 & 0.6 & 1.0 & 0.8 & 0.8\end{array}$
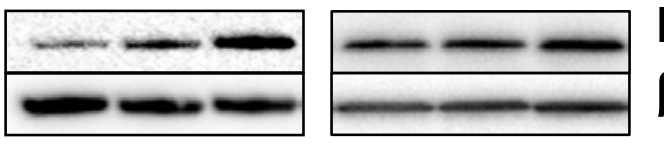

HDAC2

$\beta$-actin

$$
\begin{array}{llllll}
1.0 & 2.2 & 6.0 & 1.0 & 0.9 & 1.2
\end{array}
$$
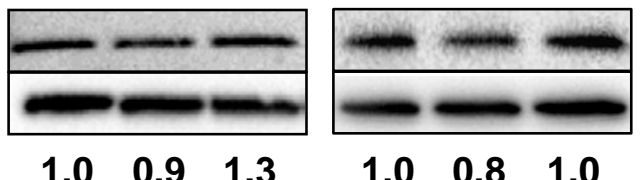

HDAC3

$\begin{array}{llllll}1.0 & 0.9 & 1.3 & 1.0 & 0.8 & 1.0\end{array}$
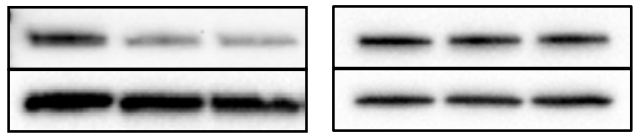

HDAC6

$\begin{array}{llllll}1.0 & 0.5 & 0.4 & 1.0 & 1.0 & 0.8\end{array}$

B

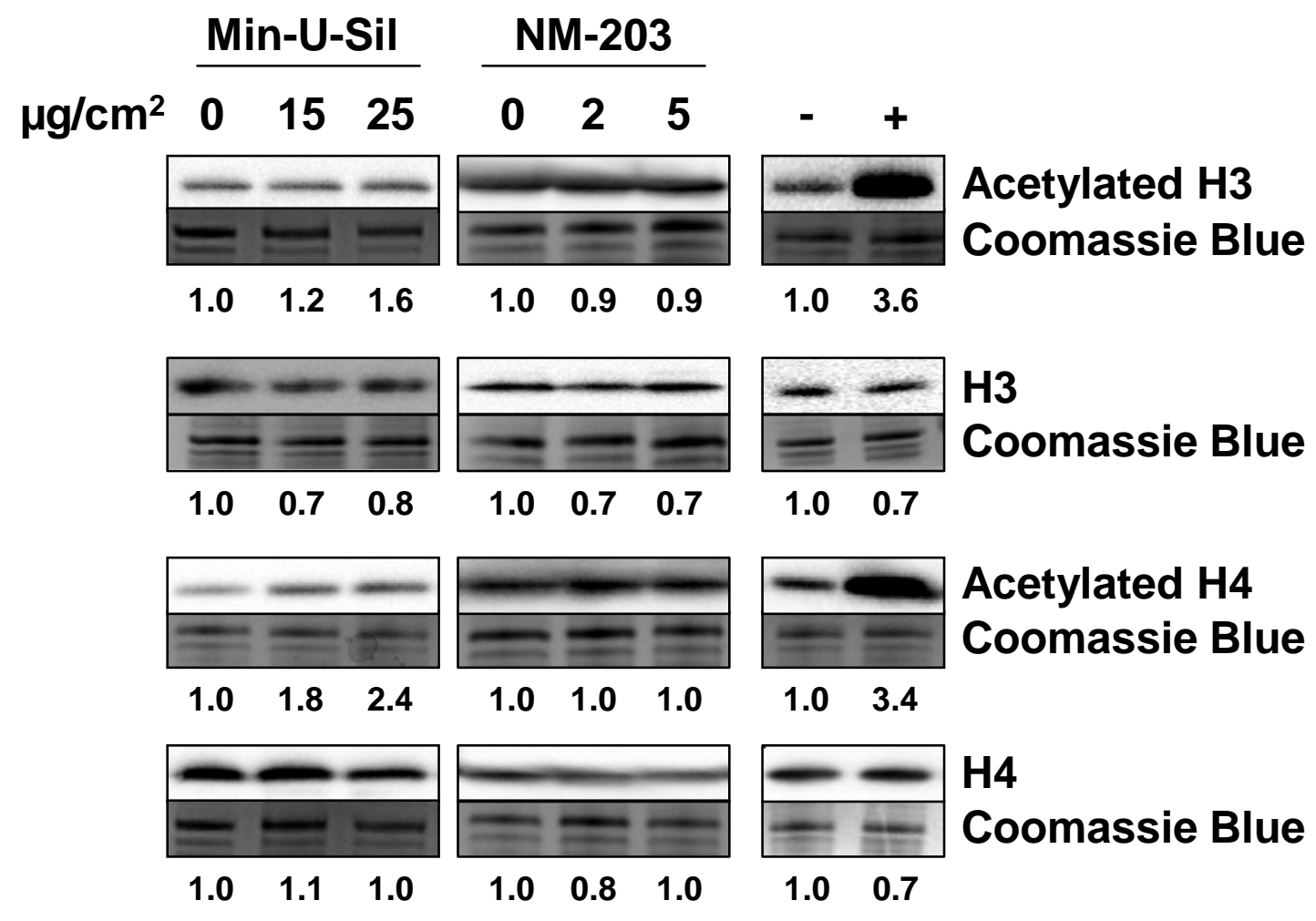


A

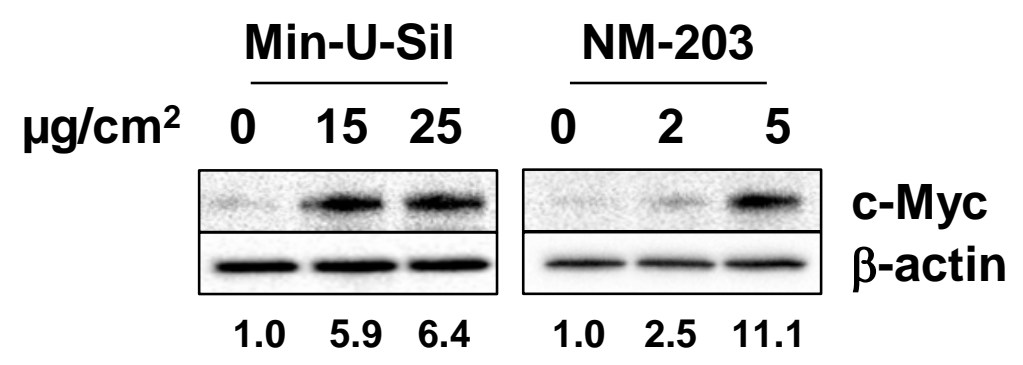

B
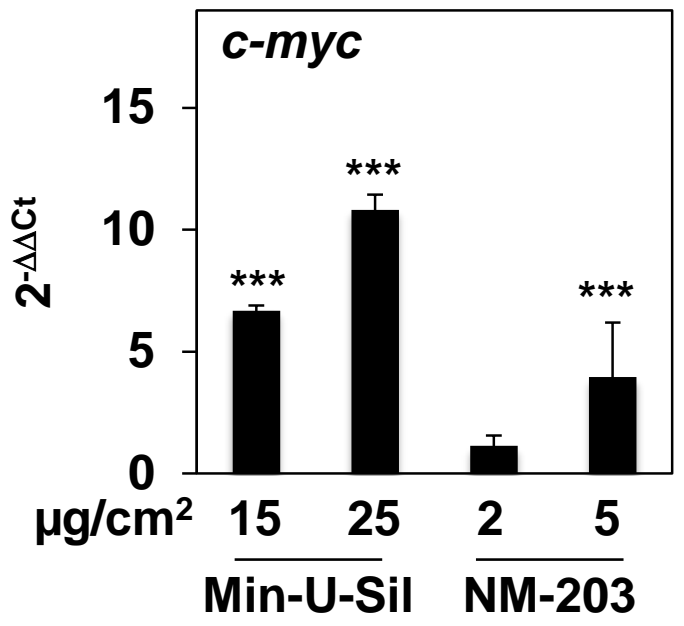

C

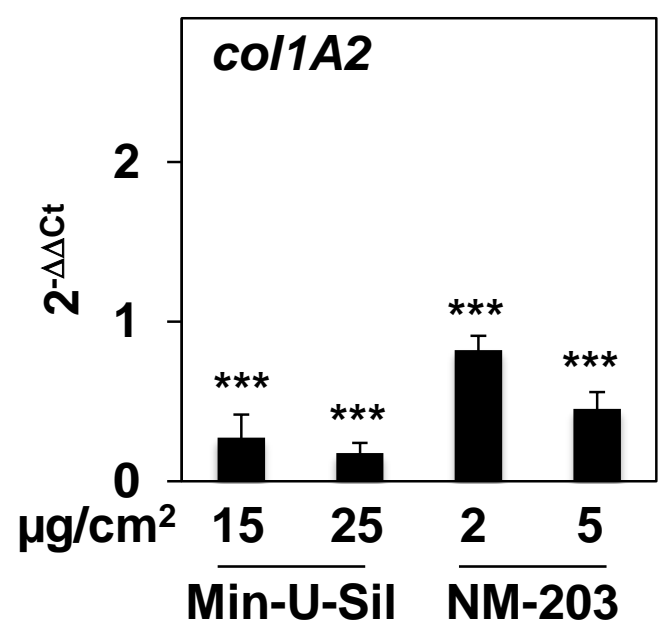


A

P1 P2

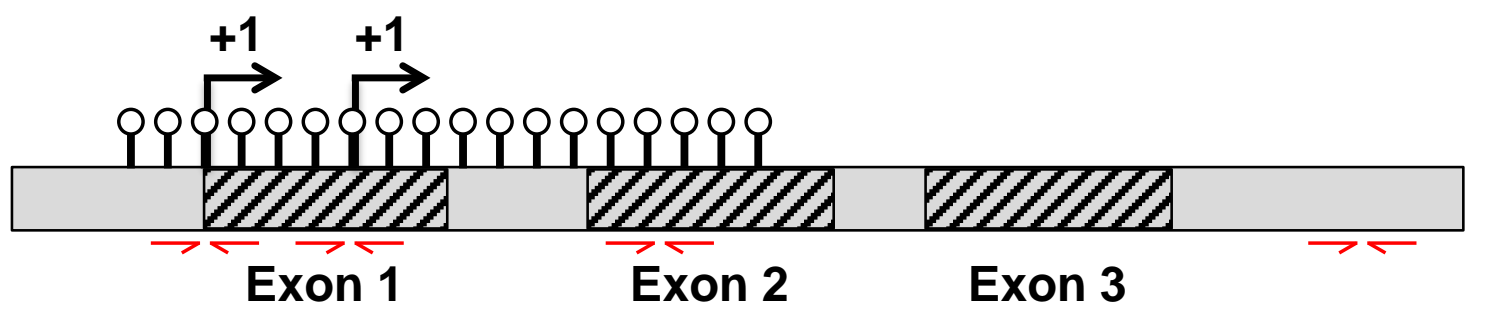

९ CpG island $\longrightarrow$ Transcription start site $\rightarrow \leftarrow \begin{aligned} & \text { Primer localization } \\ & \text { for ChIP analysis }\end{aligned}$

B

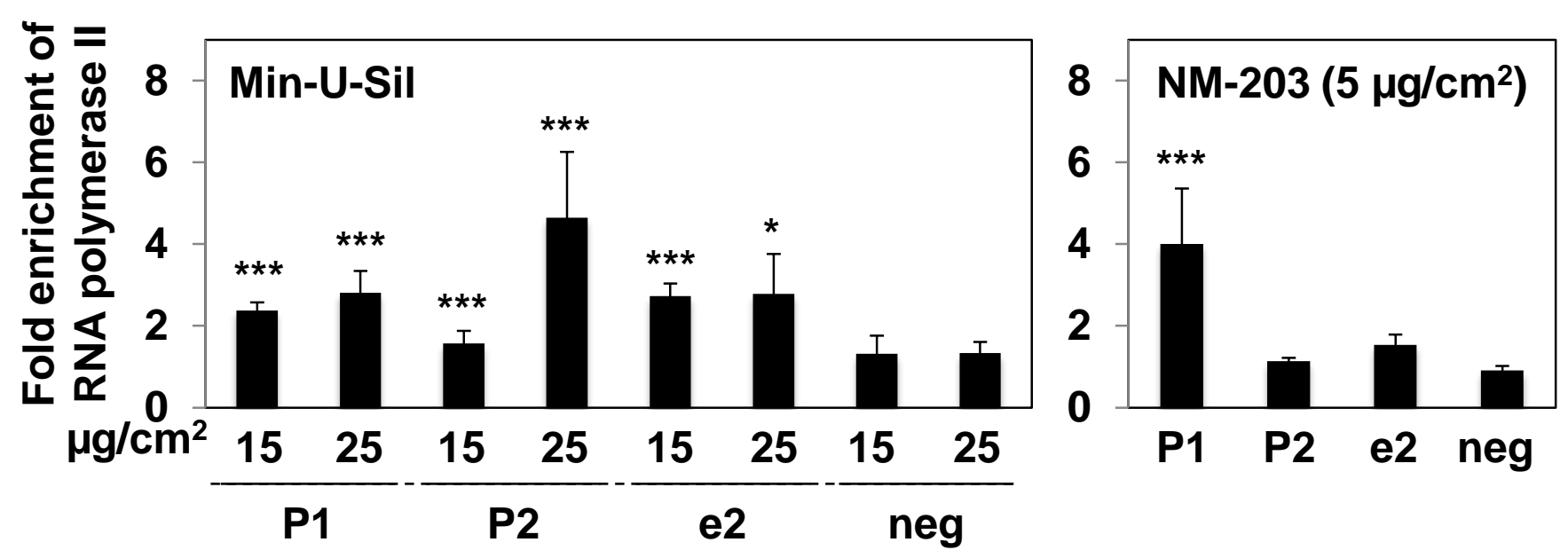

C
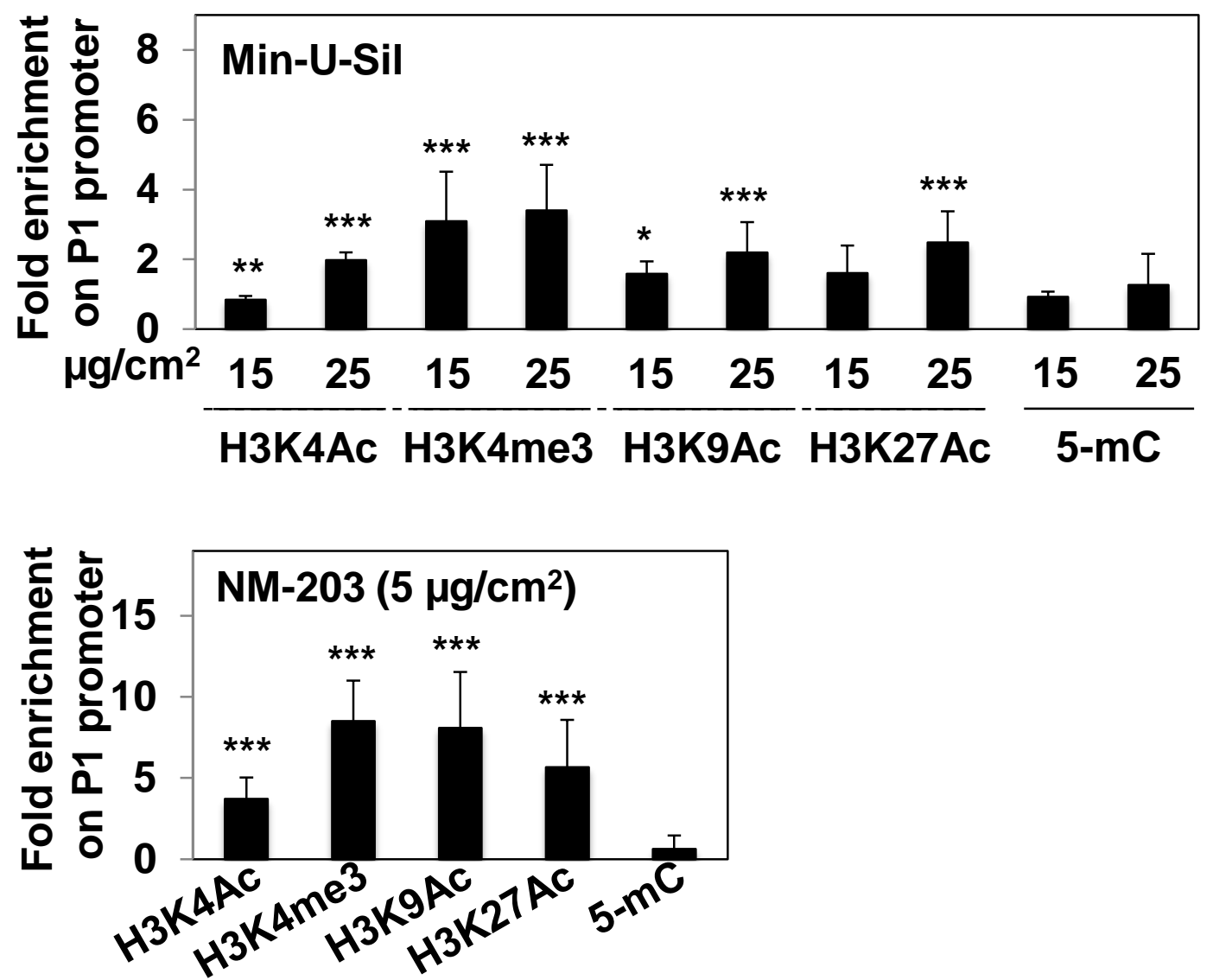
A

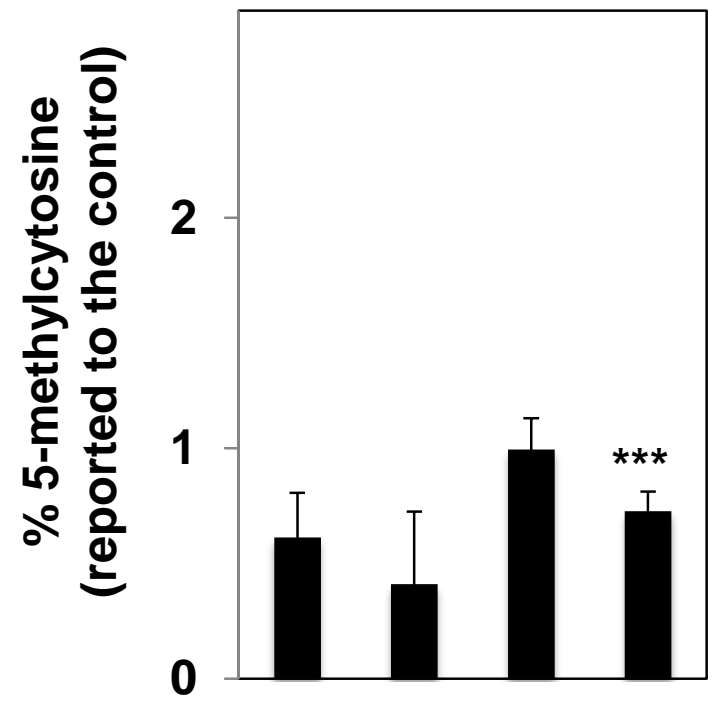
$\mu \mathrm{g} / \mathrm{cm}^{2} \quad \begin{array}{llll}15 & 25 & 5\end{array}$

Min-U-Sil NM-203
B

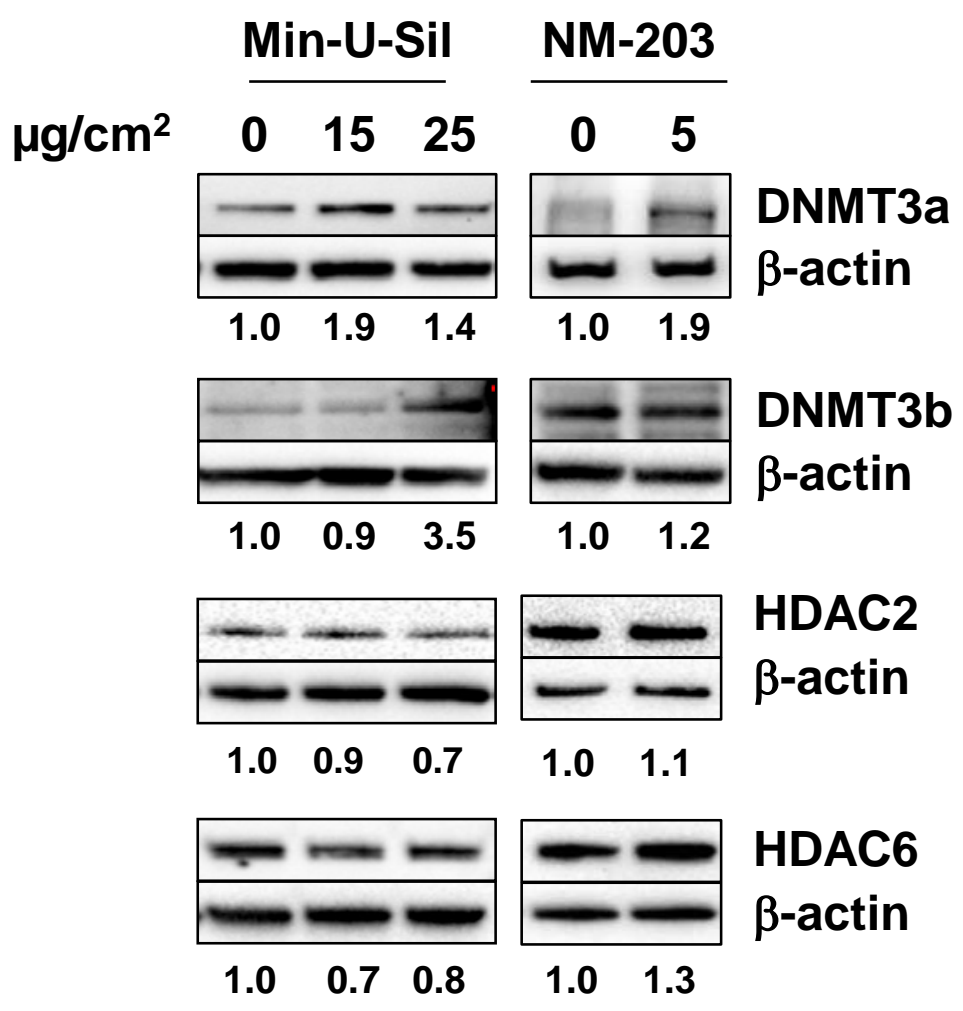

C

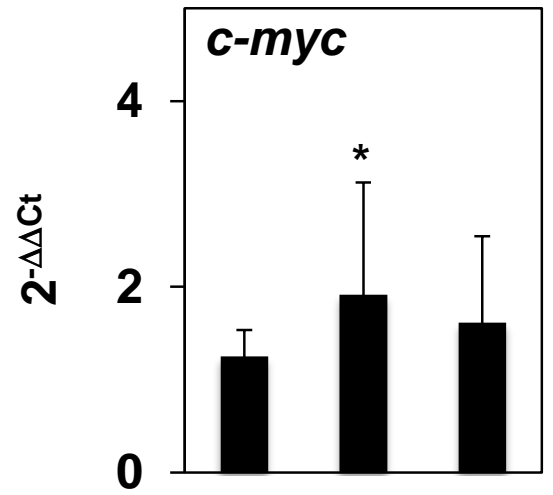

$\mu \mathrm{g} / \mathrm{cm}^{2} \quad 15 \quad 25 \quad 5$

Min-U-Sil NM-203

D

Min-U-Sil NM-203

$\begin{array}{llllll}\mu \mathrm{g} / \mathrm{cm}^{2} & 0 & 15 & 25 & 0 & 5\end{array}$
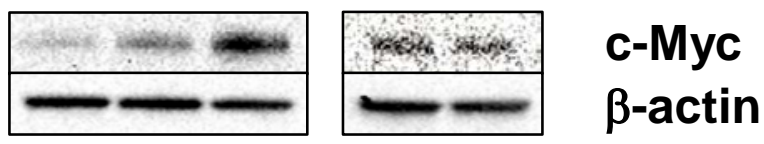

$\begin{array}{lllll}1.0 & 1.4 & 4.3 & 1.0 & 1.2\end{array}$ 